Article

\title{
Potassium Dichromate Induced Cytotoxicity, Genotoxicity and Oxidative Stress in Human Liver Carcinoma (HepG $)_{2}$ Cells
}

\author{
Anita K. Patlolla *, Constance Barnes, Diahanna Hackett and Paul B. Tchounwou \\ Molecular Toxicology Research Laboratory, NIH-Center for Environmental Health, CSET, Jackson \\ State University, Jackson, MS, USA; E-mails: constancepb@yahoo.com (C.B.); \\ diahanna.m.hackett@jsums.edu (D.H.); paul.b.tchounwou@jsums.edu (P.B.T.) \\ * Author to whom correspondence should be addressed; E-Mail: anita.k.patlolla@jsums.edu; Tel.: \\ 601-979-0210; Fax: 601-979-5853
}

Received: 11 November 2008 / Accepted: 10 February 2009 / Published: 12 February 2009

\begin{abstract}
Chromium is a widespread industrial waste. The soluble hexavalent chromium $\mathrm{Cr}$ (VI) is an environmental contaminant widely recognized to act as a carcinogen, mutagen and teratogen towards humans and animals. The fate of chromium in the environment is dependent on its oxidation state. Hexavalent chromium primarily enters the cells and undergoes metabolic reduction to trivalent chromium, resulting in the formation of reactive oxygen species together with oxidative tissue damage and a cascade of cellular events. However, the results from in vitro studies are often conflicting. The aim of this study was to develop a model to establish relationships between cytotoxicity, genotoxicity and oxidative stress, in human liver carcinoma [HepG2] cells exposed to potassium dichromate. HepG2 cells were cultured following standard protocols and exposed to various concentrations [0$50 \mu \mathrm{M}]$ of potassium dichromate $\left[\mathrm{K}_{2} \mathrm{Cr}_{2} \mathrm{O}_{7}\right]$. Following exposure to the toxic metal, the MTT assay was performed to assess the cytotoxicity, the thiobarbituric acid test to evaluate the degree of lipid peroxidation as an indicator of oxidative stress and the alkaline comet assay was used to assess DNA damage to study genotoxicity. The results of the study indicated that potassium dichromate was cytotoxic to HepG2 cells. The $\mathrm{LD}_{50}$ values of 8.83 $\pm 0.89 \mu \mathrm{g} / \mathrm{ml}, 6.76 \pm 0.99 \mu \mathrm{g} / \mathrm{ml}$, respectively, for cell mortality at 24 and $48 \mathrm{hrs}$ were observed, indicating a dose- and time-dependent response with regard to the cytotoxic effects of potassium dichromate. A statistically significant increase in the concentration of malondialdehyde [MDA], an indicator of lipid peroxidation, was recorded in exposed cells $[15.9-69.9 \mu \mathrm{M}]$ compared to control $[13 \mu \mathrm{M}]$. Similarly, a strong dose-response
\end{abstract}


relationship $(\mathrm{p}<0.05)$ was also obtained with respect to potassium dichromate induced DNA damage (comet assay) in HepG2 cells exposed [3.16 $\pm 0.70-24.84 \pm 1.86$ microns - mean comet tail length]; $[12.4 \pm 1.45 \%-76 \pm 1.49 \%-\%$ tail DNA] to potassium dichromate than control $[3.07 \pm 0.26$ microns - mean comet tail length]; $[2.69+0.19 \%-\%$ Tail DNA], respectively. The results demonstrated that potassium dichromate was highly cytotoxic to HepG2 cells, and its cytotoxicity seems to be mediated by oxidative stress and DNA damage.

Keywords: HepG2 cells, cytotoxicity, DNA damage, lipid peroxidation, malondialdehyde, potassium dichromate.

\section{Introduction}

Chromium $(\mathrm{Cr})$ is a naturally occurring heavy metal commonly found in the environment in two valence states: trivalent $\mathrm{Cr}$ (III) and hexavalent $\mathrm{Cr}$ (VI). It is widely used in numerous industrial processes and as a result, is a contaminant of many environmental systems [1]. Commercial chromium compounds are used in industrial welding, metal finishes, leather tanning and wood preservation and it is a non-negligible pollutant in the world [2,3]. Studies in animal models also found many harmful effects of $\mathrm{Cr}$ (VI) on mammals. Subcutaneous administration of $\mathrm{Cr}$ (VI) to rats caused severe progressive proteinuria, urea nitrogen and creatinine, as well as elevation in serum alanine aminotransferase activity and hepatic lipid peroxide formation [4]. Similar studies reported by Gumbleton and Nicholls [5] found that Cr (VI) induced renal damage in rats when administered by single sc injections. Bagchi et al. demonstrated that in rats $\mathrm{Cr}$ (VI) received orally in water induced hepatic mitochondrial and microsomal lipid peroxidation, as well as enhanced excretion of urinary lipid metabolites including malondialdehyde [6,7]. Moreover, some adverse health effects induced by $\mathrm{Cr}$ (VI) have been reported in humans. Reports of epidemiological investigations have shown that respiratory cancers have been found in workers occupationally exposed to $\mathrm{Cr}$ (VI) compounds [8,9]. DNA strand breaks in peripheral lymphocytes and lipid peroxidation products in urine observed in chromium exposed workers in many researches also showed evidence of the $\mathrm{Cr}$ (VI)-induced toxicity to humans $[10,11]$.

The carcinogenicity of specific chromium compounds is influenced by both the valence and the solubility of the chromium species. Chromium (VI) compounds have been reported to be more toxic and carcinogenic than chromium (III) ones [12,13] because the former can pass through cell membranes more easily than the latter [14]. Once inside the cell, $\mathrm{Cr}$ (VI) is reduced to its lower oxidation states $[\mathrm{Cr}(\mathrm{V})]$ and $[\mathrm{Cr}(\mathrm{IV})]$ and then $\mathrm{Cr}$ (III) by low molecular weight molecules, enzymatic and non-enzymatic reductants [15]. These reactive chromium intermediates are capable of generating a whole spectrum of reactive oxygen species (ROS), which is an important characteristic of $\mathrm{Cr}$ (VI) metabolism [16]. Excessive quantities of ROS generated by these reactions can cause injury to cellular proteins, lipids and DNA leading to a state known as oxidative stress [17]. Therefore, one of 
the most important damages caused by extraneous $\mathrm{Cr}$ (VI) is massive production of ROS during the reduction of $\mathrm{Cr}(\mathrm{VI})$ in the cell.

Lipid peroxidation (LPO), the oxidative catabolism of polyunsaturated fatty acids, is widely accepted as a general mechanism for cellular injury and death $[18,19]$. LPO and free radical generation are complex and deleterious processes that are closely related to toxicity [20]. LPO has been implicated in diverse pathological conditions, including atherosclerosis [21], aging [22], rheumatoid arthritis [23], and cancer [24]. It is also involved in the toxicity of pesticides [25], solvents [26] and metals [27]. The extension of the oxidative catabolism of lipid membranes can be evaluated by several endpoints, but the most widely used method is the quantification of malondialdehyde (MDA), one of the stable aldehydic products of lipoperoxidation, present in biological samples [28,29].

Although chromium and chromium-containing compounds has been the subject of important toxicology research, there exists a lack of appropriate in vitro model to understand the mechanism for cytotoxic effects, oxidative stress, and DNA damage. There is also scarcity of scientific data with respect to their toxicity in in vitro systems. Therefore, the present work was undertaken to study the role of cell proliferation, oxidative stress and DNA damage in $\mathrm{HepG}_{2}$ cells exposed to hexavalent chromium.

\section{Materials and Methods}

\subsection{Chemicals}

Potassium dichromate, sodium chloride, sucrose, Triton ${ }^{\circledR}$ X-100, hydrochloric acid, histopaque1077, $\mathrm{NaOH}$, ethanol, trypan-blue and EDTA were obtained from Sigma-Aldrich (St. Louis, MO, USA). They were of analytical grade or highest grade available. The Lipid Peroxidation (LPO) assay kit was purchased from Calbiochem (San Diego, CA, USA). Dulbecco's Modified Eagle's Minimal Essential Medium (DMEM), Phosphate buffer (pH 7.4), trypsin-EDTA, penicillin, streptomycin, fetal bovine serum (FBS) were obtained from GIBCO (New York, NY, USA). Comet assay kit was purchased from Trevigen, Inc., (Gaithersburg, MD). Human liver carcinoma, HepG 2 cells were purchased from ATCC (Manassas, VA). Sterile Tissue culture flask and sterile glass pippets were purchased from Fischer-Scientific.

\subsection{Cell Culture and Cytotoxicity}

Parental $\mathrm{HepG}_{2}$ cells stored in liquid nitrogen were thawed by gentle agitation of their containers (vials) for $2 \mathrm{~min}$ in a water bath at $37^{\circ} \mathrm{C}$. After thawing, the content of each vial was transferred to a $75 \mathrm{~cm}^{2}$ surface area, tissue culture flask, diluted with DMEM supplemented with $10 \%$ fetal bovine serum (FBS) and 1\% streptomycin and penicillin. Then the cells are incubated for $24 \mathrm{~h}$ at $37{ }^{\circ} \mathrm{C}$ in a $5 \% \mathrm{CO}_{2}$ incubator to allow the cells to grow, and form a monolayer in the flask. Cells grown to 8095\% confluency were washed with phosphate buffer saline (PBS), trypsinized with $3 \mathrm{~mL}$ of $0.25 \%(\mathrm{v})$ trypsin- $0.03 \% / \mathrm{v})$ EDTA, diluted, counted and seeded $\left(5 \times 10^{5}\right.$ cells/well) in two sets of 96-well microtiter tissue culture plates. 
Seeded plates were incubated for $24 \mathrm{~h}$ at $37{ }^{\circ} \mathrm{C}$ in a $5 \% \mathrm{CO}_{2}$ incubator. The old medium was replaced by $180 \mu \mathrm{L}$ of fresh medium. Twenty micro liters of serial dilutions of potassium dichromate $(0,3.125,6.25,12.5,25$ and $50 \mu \mathrm{M})$ were added column wise to the 96-well microtiter tissue culture plates and incubated for 24 and $48 \mathrm{~h}$ exposure time. Cell viability assay was performed using the MTT \{3-(4,5-dimethylthiazol-2-yl)-2,5-diphenyl-tetrazolium bromide $\}$ method. The absorbance was read at a wavelength of $550 \mathrm{~nm}$ using microtiter plate reader (Bio-Tek Instruments Inc.).

\subsection{ROS Detection}

ROS production was quantified by the DCFH-DA method [30] based on the ROS-dependent oxidation of DCFH-DA to DCF. An aliquot of cell suspension from each of the four treated and the control was centrifuged at $1000 \mathrm{x} g$ for $10 \mathrm{~min}\left(4^{\circ} \mathrm{C}\right)$. The supernatants were re-centrifuged at $20,000 \mathrm{x}$ $\mathrm{g}$ for $20 \mathrm{~min}$ at $4{ }^{\circ} \mathrm{C}$, and then the pellet was re-suspended. The DCFH-DA solution with the final concentration of $50 \mu \mathrm{M}$ and re-suspension were incubated for $30 \mathrm{~min}$ at $37{ }^{\circ} \mathrm{C}$. Fluorescence of the samples was monitored at an excitation wavelength of $485 \mathrm{~nm}$ and an emission wavelength of $538 \mathrm{~nm}$.

\subsection{Comet Assay}

DNA damage was determined in $\mathrm{HepG}_{2}$ cells exposed to four doses of potassium dichromate and control for $48 \mathrm{~h}$ using comet assay kit from Trevigen (Gaithersburg, MD). Following isolation the cells were mixed with $0.4 \%$ Trypan blue solution, after 15-20 min cells were counted and checked for viability. The remaining cells were immediately used for single-cell gel electrophoresis. The assay was performed according to Singh et al. [31] with slight modifications. All the steps were conducted under yellow lamp in the dark to prevent additional DNA damage. Stained Slides are viewed under automated robotic epiflorescent microscope. A total of 150 individual cells were screened/sample [duplicate, each with 75 cells. Slides were read using DNA damage analysis software [Loats Associates Inc., Westminster, MD]. Each experiment was performed in triplicate. Cells with damaged DNA displayed high migration of DNA fragments from the nucleus, forming a tail in comet form. Most important parameters besides mean comet tail length that were used for analyzing genotoxicity in the comet assay were:

DNA head (DNAH), sum of intensities of all points of the head.

DNA tail (DNAT), sum of intensities of all points of the tail.

Percent tail DNA $(\%$ DNAT $)=100 \mathrm{DNAT} /(\mathrm{DNAH}+\mathrm{DNAT})$

\subsection{Malondialdehyde (MDA) Determination}

Malondialdehyde concentration was measured in $\mathrm{HepG}_{2}$ exposed to four doses of potassium dichromate and a control for $48 \mathrm{~h}$ using lipid peroxidation assay kit from Calbiochem (San Diego, CA, USA). Briefly, $0.65 \mathrm{~mL}$ of $10.3 \mathrm{mM} \mathrm{N}$-methyl-2-phenylindole in acetonitrile was added to $0.2 \mathrm{~mL}$ of sample. After vortexing for $3-4 \mathrm{sec}$ and adding $0.15 \mathrm{~mL}$ of $37 \% \mathrm{HCl}$, samples were mixed well and closed with a tight stopper and incubated at $45^{\circ} \mathrm{C}$ for 60 mins. The samples were then cooled on ice, centrifuged and the absorbance was measured spectrophotometrically at $586 \mathrm{~nm}$. A calibration curve 
of an accurately prepared standard MDA solution (from 2-20 nmol/mL) was also run for quantification. Measurements of each group were performed in triplicate. The standard deviations were less than $\pm 10 \%$.

\section{Data Analysis and Statistics}

Data were compared by ANOVA. Statistical analysis was performed using SAS for Windows 2003 package program. Using the Dunnett test, multiple comparisons were performed. All values were reported as means $\pm \mathrm{SD}$ for all the experiments. The significance level was set at $p<0.05$.

\section{Results}

\subsection{Cytotoxicity Assay}

The MTT result of the cytotoxic effect of potassium dichromate on human liver carcinoma cells following 24 and $48 \mathrm{~h}$ of exposure is shown in Figure 1. This figure indicates a strong dose- and timedependent response relationship with respect to chromium toxicity. After $48 \mathrm{~h}$ of exposure, the percentages of cell viability were $100 \pm 0.0,82.0 \pm 12.0,55.0 \pm 5.8,40.0 \pm 12.0$, and $35.0 \pm 3.7 \%$ for the control, 3.12, 6.25, 12.5 and $25 \mu \mathrm{M}$ of potassium dichromate respectively. The dose of potassium dichromate required to produce $50 \%$ reduction in the viability of $\mathrm{HepG}_{2}$ cells $\left(\mathrm{LD}_{50 \mathrm{~s}}\right)$ were compound to be $8.83 \pm 3.5$ and $6.76 \pm 0.7 \mu \mathrm{g} / \mathrm{mL}$ upon 24 and $48 \mathrm{~h}$ of exposure, respectively; indicating a doseand time-dependent response with regard to the cytotoxic effect of potassium dichromate.

Figure 1. Cytotoxicity after 24 and $48 \mathrm{~h}$ exposure to potassium dichromate in HepG2 cells using MTT assay. Each experiment was done in triplicate. Data were represented as means \pm SDs. Statistical significance was indicated as $(*)$ for $(\mathrm{p}<0.05)$.

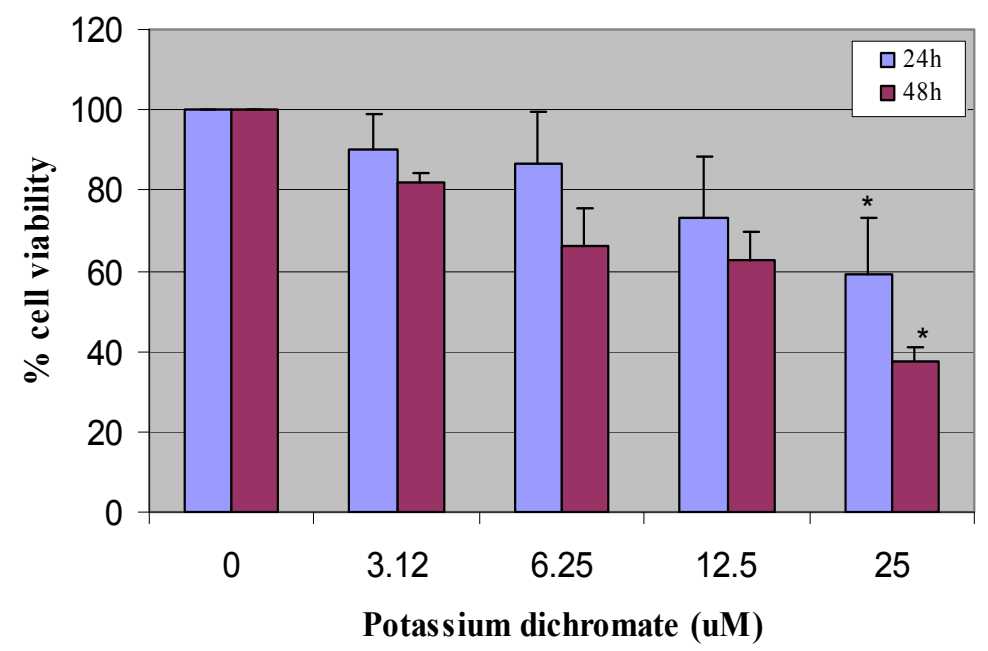




\subsection{ROS Detection}

ROS were determined in control and exposed groups after administration of potassium dichromate to $\mathrm{HepG}_{2}$ for $48 \mathrm{~h}$. The exposure of $\mathrm{Cr}$ (VI) to $\mathrm{HepG}_{2}$ cells significantly enhanced the ROS level at four tested doses as compared to the control group and increases were found to show dose-dependent relationship. Figure2. Represent the result of ROS detection.

Figure 2. Potassium dichromate induced ROS in HepG2 cells. Each experiment was done in triplicate. Data were represented as means \pm SDs. Statistical significance was indicated as $(*)$ for $(\mathrm{p}<0.05)$.

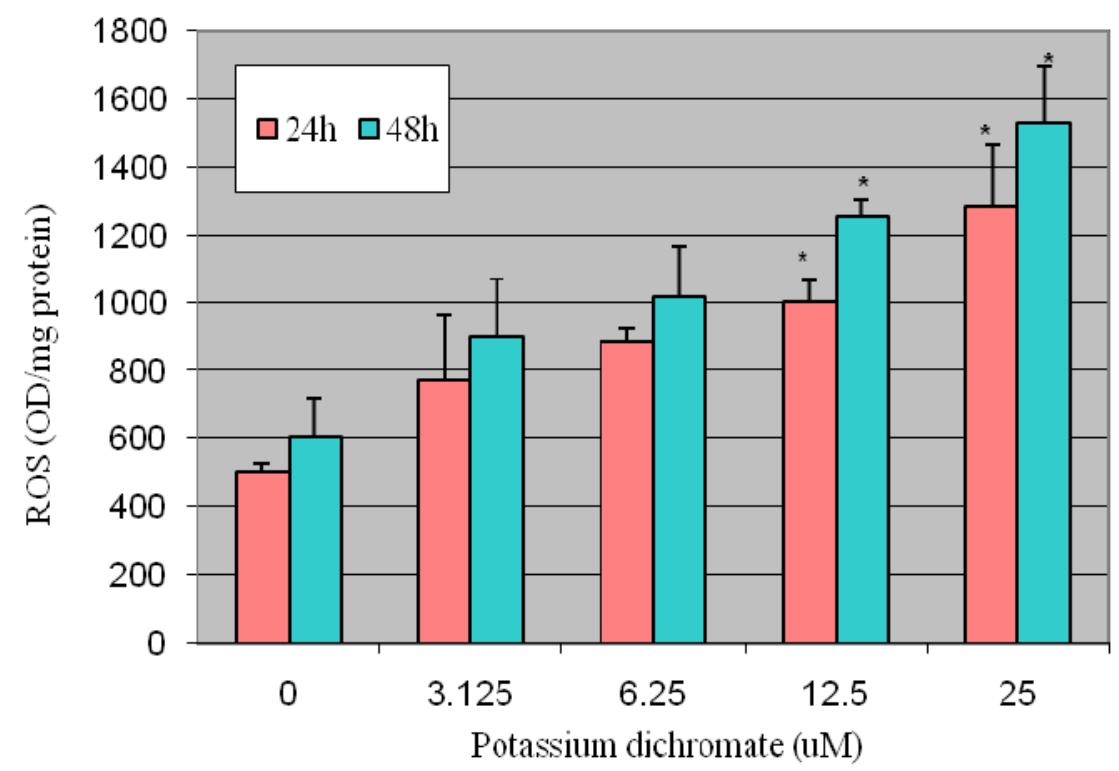

\subsection{DNA Damage [Comet assay]}

Comet tail length is an important parameter in evaluating the DNA damage. All the doses of potassium dichromate induced statistically significant increase in mean comet tail length [3.16 $\pm 0.7-$ $24.8 \pm 1.86$ microns] indicating DNA damage when compared with controls [3.07 \pm 0.26 microns]. Maximum increase in mean comet tail length was observed at $25 \mu \mathrm{M}$ at $48 \mathrm{~h}$ post-treatment [24.8 microns]. Besides the mean comet tail length, percent tail DNA was also measured in the exposed and control cells. The following percent tail DNA $12.4 \pm 1.45 \%, 19.2 \pm 1.16 \%, 32.6 \pm 5.79$ and $76 \pm$ $1.49 \%$ respectively was observed in the HepG2 cells exposed to various concentration of potassium dichromate compared to control $2.69 \pm 0.19 \%$. The mean comet tail length showed a clear dosedependent increase from 3.12 to $25 \mu \mathrm{M}$. The results of DNA damage cells are illustrated in Figure 3(A) (B) and (C) respectively. Representative comet assay images of control (A) and potassium dichromate treated $\mathrm{HepG}_{2}$ cells at $3.12 \mu \mathrm{M}(\mathrm{B}) ; 6.25 \mu \mathrm{M}(\mathrm{C}) ; 12.5 \mu \mathrm{M}(\mathrm{D})$ and $25 \mu \mathrm{M}(\mathrm{E})$ are presented in Figure3A. Genotoxicity as characteristized by the length of the comet tail is illustrated in Figure 3B. 
Figure 3. (A) Single Cell Gel Electrophoresis assessment of potassium dichromate toxicity in human liver carcinoma cells (HepG2): A) Representative Comet images of control (A), and $3.12 \mu \mathrm{M}(\mathrm{B}) ; 6.25 \mu \mathrm{M}(\mathrm{C}) ; 12.5 \mu \mathrm{M}$ (D) and $25 \mu \mathrm{M}(\mathrm{E}) ; 3(\mathrm{~B})$ : Effect of various doses of potassium dichromate and control on DNA migration in $\mathrm{HepG}_{2}$ cells at $48 \mathrm{~h}$ exposure; 3(C): Effect of various doses of potassium dichromate and control on the percent tail DNA. Each experiment was done in triplicate. Data were represented as means \pm SDs. Statistical significance was indicated as $(*)$ for $(\mathrm{p}<0.05)$.

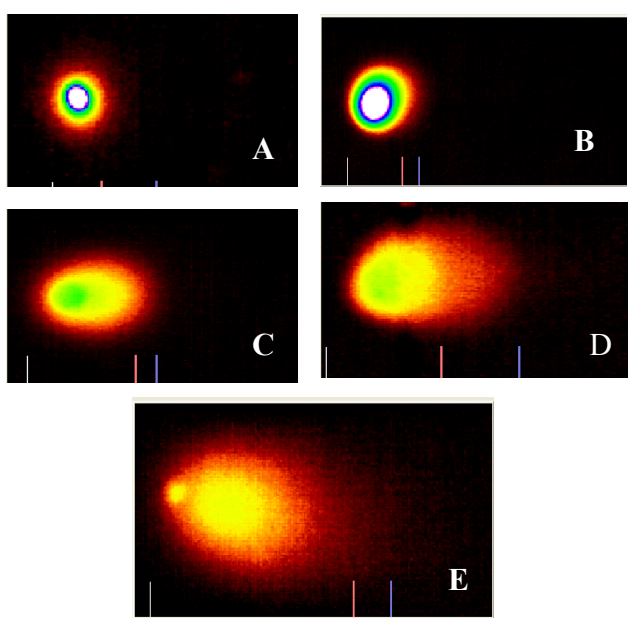

3A

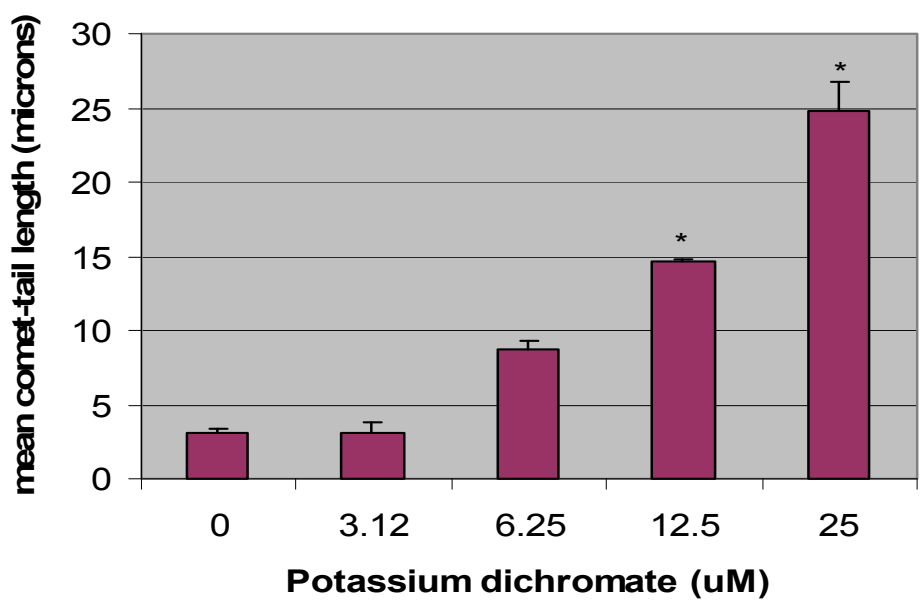

$3 B$

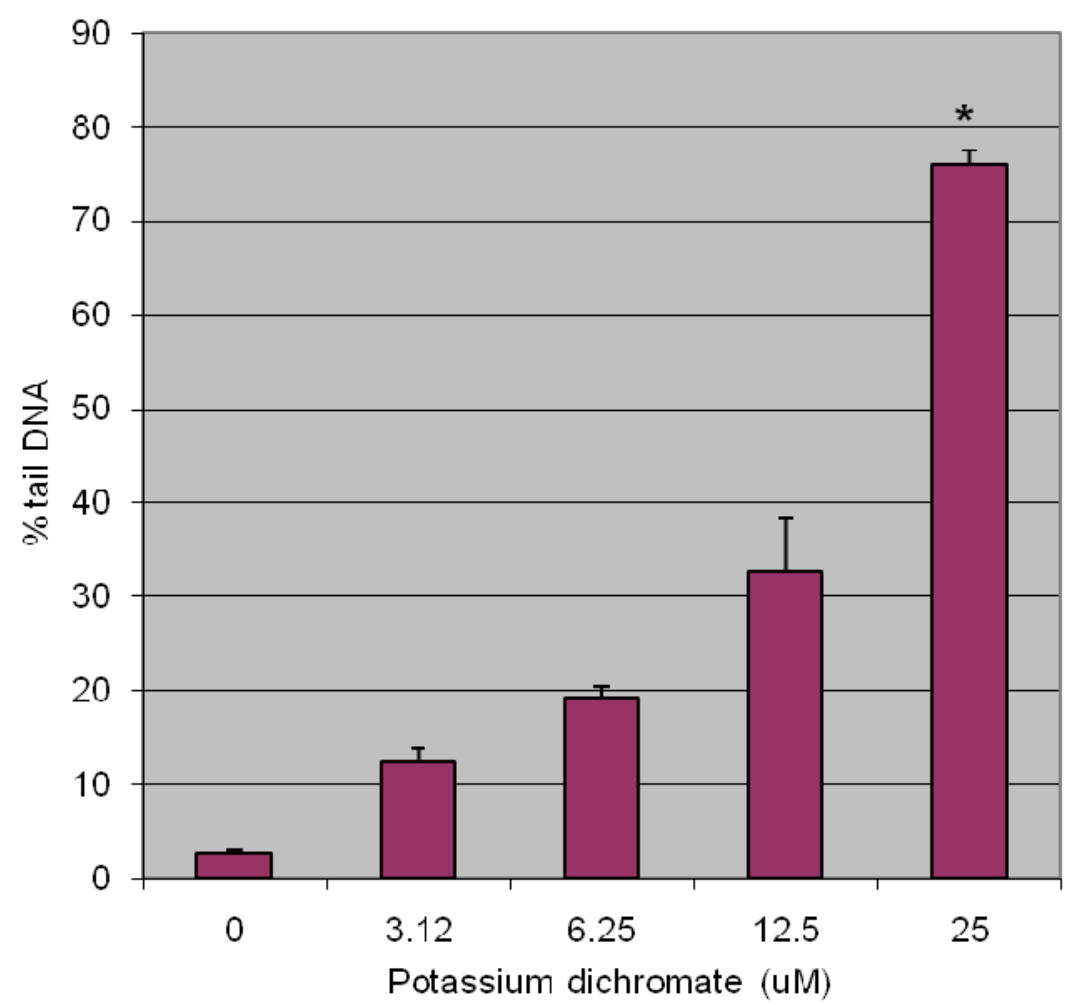

$3 \mathrm{C}$ 


\subsection{Lipid Peroxidation}

One of the methods for evaluating lipid peroxidation is measurement of malondialdehyde concentration in the cells. Potassium dichromate exposure significantly $(p<0.05)$ increased the concentration of MDA in $\mathrm{HepG}_{2}$ cells when compared with the control. Results are illustrated in Figure 4. The increase in MDA concentration in $\mathrm{HepG}_{2}$ was found to be dose-dependent, indicating a gradual increase with increasing dose of potassium dichromate. Statistically significant increase in the concentration of malondialdehyde [MDA], an indicator of lipid peroxidation, was recorded in exposed cells $[15.9-69.9 \mu \mathrm{M}]$ compared to control $[13 \mu \mathrm{M}]$.

Figure 4. Induction of lipid peroxidation in HepG2 cells by various doses of potassium dichromate and control. Each experiment was done in triplicate. Data were represented as mean \pm SD. Statistical significance was indicted as $(*)$ for $(\mathrm{p}<0.05)$.

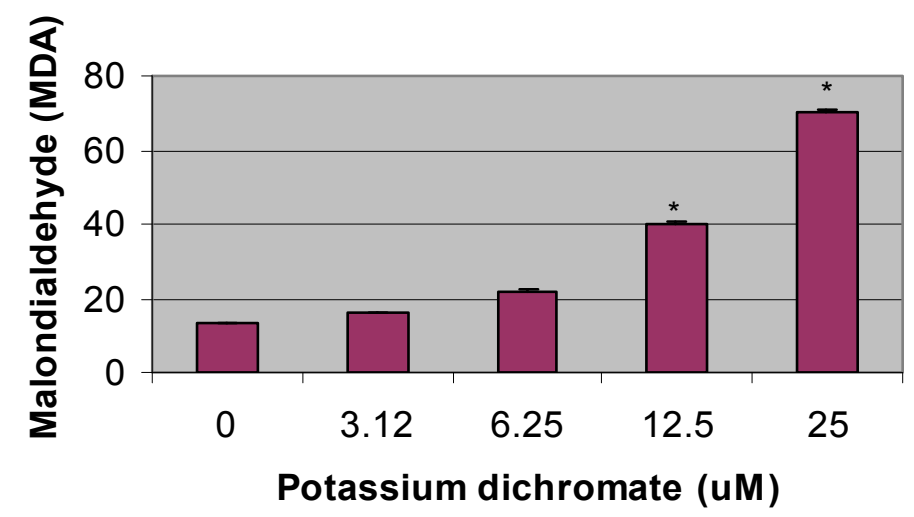

\section{Discussion}

In the present study concentration- and time-dependent effects of potassium dichromate were assessed on the reductions of tetrazolium dye MTT in cultured $\mathrm{HepG}_{2}$ cells. This is a marker of succinate dehydrogenase activity, an index of the mitochondrial electron transport system, which is used to assess cell viability. Only viable cells with intact mitochondria can reduce tetrazolium dye MTT and the amount of MTT reduced is directly proportional to the number of viable cells present. Data obtained from the present study, clearly indicate that potassium dichromate is highly cytotoxic to human liver carcinoma cells. The $\mathrm{LD}_{50}$ were computated to be $8.83 \pm 3.5$ and $6.76 \pm 0.7 \mu \mathrm{g} / \mathrm{mL}$ after 24 and $48 \mathrm{~h}$ of exposure, respectively; indicating a dose- and time-dependent response with regards to the cytotoxic effect of potassium dichromate. These results support those of a previous investigation reporting a marked reduction in the viability of K562 and J774 cells exposed to chromium (VI) [32].

In this study we observed that there was a significant increase in the level of ROS in $\mathrm{HepG}_{2}$ cells exposed to potassium dichromate compared to control. Reactive oxygen species (ROS) have been implicated in the toxicity of chromium (VI) by several authors [7,15,33]. Their formation with subsequent cellular damage is considered as the common molecular mechanism of Cr (VI)-induced toxicity. According to this hypothesis, chromium (VI) itself is not a cytotoxic agent but rather an oxygen free radical generator through cellular reduction to chromium (VI) [34]. Chromium reduction intermediates are believed to react with hydrogen peroxide to form the hydroxyl radical [35], which 
may finally attack proteins, DNA, and membranes lipids thereby disrupting cellular functions and integrity [7].

In the present study, measuring the concentration of $\mathrm{MDA}$ in $\mathrm{HepG}_{2}$ of potassium dichromateexposed and control group assessed lipid peroxidation. There was a significant increase in the concentration of MDA after $48 \mathrm{~h}$ of potassium dichromate administration. These results are in accordance with those obtained by Bagchi et al. [32], who detected oxidative lipid metabolites in K562 and $\mathrm{J} 774$ cells exposed to $\mathrm{Cr}$ (VI). The increase observed in lipid peroxidation may be due to the formation of hydroxyl radical (HO) through a Fenton/Haber-Weiss reaction, catalysed by chromium. This radical is capable of abstracting a hydrogen atom from a methylene group of polyunsaturated fatty acids enhancing lipid peroxidation.

The frequency of single-strand breaks showed a clear dose-related increase in $\mathrm{HepG}_{2}$ cells up to 25 $\mu \mathrm{M}$ in our investigation. Maximum DNA damage was observed at $48 \mathrm{~h}$ post-treatment when compared with the controls. Similar results were reported with other heavy metals in rodents and in other celllines using comet assay [3,36]. Cr (VI) itself is not reactive to DNA, however, the chromium metabolites radicals produced during reduction can subsequently attack macromolecules and lead to multiform DNA damages e.g. strand breakage, DNA-protein cross-links, DNA-DNA cross-links, CrDNA adducts and base modifications in cells. Especially DNA strand breaks are mainly ascribed to the ROS $[3,37,38]$. Single cell gel electrophoresis (comet assay) is a highly sensitive technique to evaluate single strand breaks and alkali labile sites in DNA of individual cells.

In summary, the current study demonstrates that administration of $\mathrm{Cr}$ (VI) to human liver carcinoma cells for $48 \mathrm{~h}$ could induce cytotoxicity, DNA damage and oxidative stress. ROS may play an essential role in DNA damage and oxidative stress induced by $\mathrm{Cr}$ (VI) in vitro. Our results show that the use of thiobarbituric acid reactive substances (TBARS) as a marker of oxidative stress should be complemented with antioxidant parameters namely SOD and CAT. The results support an involvement of the oxidative damage pathway in the mechanism of toxicity of chromium. Further studies of the behavior of the antioxidant enzymes can aid in the understanding of chromium-induced toxicity.

\section{Acknowledgements}

This research was financially supported by a grant from the National Institutes of Health - (Grant No 1G12RR13459), through the RCMI-Center for Environmental Health at Jackson State University. . The authors thank Dr. Abdul K. Mohamed, Dean Emeritus, and the RCMI external advisory committee members, for their technical support in this project.

\section{References}

1. Cohen, M.D.; Kargacin, B.; Klein, C.B.; Costa, M. Mechanisms of chromium carcinogenicity and toxicity. Crit. Rev. Toxicol. 1993, 23, 255-281.

2. Norseth, T. The carcinogenicity of chromium - Review. Environ. Health. Perspect. 1981, 40, 121 30 .

3. Wang, X.F.; Xing, M.L.; Shen, Y.; Zhu, X.; Xu, L.H. Oral administration of Cr (VI) induced oxidative stress, DNA damage and apoptotic cell death in mice. Toxicology. 2006, 228, 16-23. 
4. Kim, E.; Na, K.J. Nephrotoxicity of sodium dichromate depending on the route of administration. Arch. Toxicol. 1991, 65, 537-541.

5. Gumbleton, M.; Nicholls, P.J. Dose-response and time-response biochemical and histological study of potassium dichromate-induced nephrotoxicity in the rat. Food Chem.Toxicol. 1988, 26, 37-44.

6. Bagchi, D.; Hassoun, E.A.; Bagchi, M.; Muldoon, D.; Stohs, S.J. Oxidative stress induced by chronic administration of sodium dichromate (Cr VI) to rats. Comp. Biochem. Physiol. 1995a, 110C, 281-287.

7. Bagchi, D.; Vuchetich, P.J.; Bagchi, M.; Hassoun, E.A.; Tran, M.X.; Tang, L.; Stohs, S.J. Induction of oxidative stress by chronic administration of sodium dichromate (chromium VI) and cadmium chloride (cadmium II) to rats. Free Rad. Biol. Med. 1997b, 22, 471-478.

8. Costa, M. Toxicity and carcinogenicity of Cr (VI) in animal models and humans. Crit. Rev. Toxico. 1997, 27, 431-42. Review.

9. Dayan, A.D.; Paine, A.J. Mechanisms of chromium toxicity, carcinogenicity and allergenicity: review of the literature from 1985 to 2000. Hum. Exp. Toxicol. 2001, 20, 439-51. Review.

10. Gambelunghe, A.; Piccinini, R.; Ambrogi, M.; Villarini, M.; Moretti, M.; Marchetti, C.; Abbritti, G.; Muzi, G. Primary DNA damage in chrome-plating workers. Toxicology 2003, 188, 187-95.

11. Goulart, M.; Batoreu, M.C.; Rodrigues, A.S.; Laires, A.; Rueff, J. Lipoperoxidation products and thiol antioxidants in chromium exposed workers. Mutagenesis 2005, 20, 311-15.

12. Connett, P.H.; Wetterhahn, K.E. Metabolism of carcinogenic chromate by cellular constituents. Struct. Bonding 1983, 54, 93-24.

13. De Flora, S.; Bagnasco, M.; Serra, D.; Zanacchi, P. Genotoxicity of chromium compounds: a review. Mutat. Res. 1990, 238, 99-172.

14. De Flora, S.; Wetterhahn, K.E. Mechanisms of chromium metabolism and genotoxicity. Life Chem. Rep. 1989, 7, 169-244.

15. Shi, X.; Chiu, A.; Chen, C.T.; Halliwell, B.; Castranova, V.; Vallyathan, V. Reduction of chromium (VI) and its relationship to carcinogenesis. J. Toxicol. Environ. Health 1999, 2, 87-104.

16. O' Brien, T.J.; Ceryak, S.; Patierno, S.R. Complexities of chromium carcinogenesis: role of cellular response, repair and recovery mechanisms. Mutat. Res. 2003, 533, 3-36.

17. Nordberg, J.; Arner, E.S. Reactive oxygen species, antioxidants, and the mammalian thioredoxin system. Free Radical Biol. Med. 2001, 31, 1287-1312.

18. Gutteridge, J.M.C.; Quinlan, G.J. Malondialdehyde formation from lipid peroxides in thiobarbituric acid test. The role of lipid radicals, iron salts and metal chelator. J. Appl. Biochem. 1983, 5, 293-299.

19. Halliwell, B. Oxygen radicals: A common sense look at their nature and medical importance. Med. Biol. 1984, 62, 71-77.

20. Murray, R.K.; Granner, D.K.; Mayes, P.A.; Rodwell, V.W. Harper's Biochemistry, $21^{\text {st }}$ Edition; Prentice Hall: NJ, USA, 1988; pp. 138-139.

21. Holvoet, P.; Collen, D. Oxidation of low density lipoproteins in the pathogenesis of atherosclerosis. Atherosclerosis 1998, 137 (Suppl.), S33-S38.

22. Spiteller, G. Lipid peroxidation in aging and age-dependent diseases. Exp. Gerontol. 2001, 36, 1425-1457. 
23. Henrotin, Y.; Deby-Dupont, G.; Deby, C.; Franchimont, P.; Emerit, I. Active oxygen species, articular inflammation and cartilage damage. EXS 1992, 62, 308-322.

24. Marnett, L.J. Oxyradicals and DNA damage. Carcinogenesis 2000, 21, 361-370.

25. Bismuth, C.; Garnier, R.; Baud, F.J.; Muszynski, J.; Keyes, C. Paraquat poisoning; An overview of current status. Drug Saf. 1990, 5, 243-251.

26. Brattin, W.J.; Glende, E.A.; Recknagel, R.O. Pathological mechanisms in carbon tetrachloride hepatotoxicity. J. Free Radic. Biol. Med. 1985, 1, 27-38.

27. Kasprzak, K.S. Possible role of oxidative damage in metal induced carcinogensis. Cancer Inv. 1995, 13, 411-430.

28. De Zwart, L.L.; Meerman, J.H.; Commandeur, J.N.; Vermeulen, N.P. Biomarkers of free radical damage applications in experimental animals and in humans. Free Radic. Biol. Med. 1999, 26, 202-226. Review.

29. Gutteridge, J.M.C. Lipid peroxidation and antioxidants as biomarkers of tissue damage. Clin. Chem. 1995, 41, 1819-1828.

30. Lawler, J.M.; Song, W.; Demaree, S.R. Hindlimb unloading increases oxidative stress and disrupts antioxidant capacity in skeletal muscle. Free Radical. Biol. Med. 2003, 35, 9-16.

31. Singh, N.P.; McCoy, M.T.; Tice, R.R.; Schneider, E.L. A simple technique for quantitation of low levels of DNA damage in individual cells. Exp. Cell Res. 1988, 175, 184-191.

32. Bagchi, D.; Bagchi, M.; Stohl, S.J. Chromium (VI)-induced oxidative stress, apoptotic cell death and modulation of p53 tumor suppressor gene. Mol. Cell Biochem. 2001, 222, 149-158.

33. Sugiyama, M. Role of physiological antioxidants in Cr (VI) induced cellular injury. Free Rad. Biol. Med. 1992, 12, 397-407.

34. Miesel, R.; Kroger, H.; Kurpisz, M.; Wesser, U. Induction of arthritis in mice and rats by potassium peroxochromate and assessment of disease activity by whole blood chemiluminescence and 99mpertechnetate-imaging. Free Radic. Res. 1995, 23, 213-227.

35. Kadiiska, M.B.; Xiang, Q.H.; Mason, R.P. In vivo free radical generation by chromium (VI): An electron-spin resonance spin-trapping investigation. Chem. Res. Toxicol. 1994, 7, 800-805.

36. Dana Devi, K.; Rozati, R.; Saleha Banu, B.; Jamil, K.; Grover, P. In vivo genotoxic effect of potassium dichromate in mice leukocytes using comet assay. Food Chem. Toxicol. 2001, 39, 859865.

37. Wise, S.S.; Holmes, A.L.; Wise, J.P. Sr. Hexavalent chromium-induced DNA damage and repair mechanisms. Rev Environ Health. 2008, 23, 39-57.

38. Blasiak, J.; Kowalik, J. A comparison of the in vitro genotoxicity of tri and hexavalent chromium. Mutat Res. 2000, 469, 135-145.

(C) 2009 by the authors; licensee Molecular Diversity Preservation International, Basel, Switzerland. This article is an open-access article distributed under the terms and conditions of the Creative Commons Attribution license (http://creativecommons.org/licenses/by/3.0/). 